\title{
WOLNOŚĆ WYPOWIEDZI I WOLNOŚĆ WYZNANIA W KOLIZJI ZE SKUTKIEM ŚMIERTELNYM. UWAGI WYBRANE NA KANWIE WYROKU ETPC Z DNIA 5 GRUDNIA 2019 R. W SPRAWIE Tagiyev i Huseynov v. Azerbejdżan
}

\section{Wstęp}

Wraz z rozwojem nowoczesnych mediów o zasięgu globalnym, w szczególności działających w oparciu o sieć internetową, w obliczu różnorodnych kryzysów powstających w wielu miejscach świata jesteśmy świadkami postępującej radykalizacji rozpowszechnianych w przestrzeni publicznej poglądów i przekonań przedstawicieli rożnych grup społecznych. To w naturalny sposób prowadzi do trudnej do uniknięcia i coraz ostrzejszej ich konfrontacji. W optyce prawa mamy do czynienia z kolizją praw i wolności konfrontujących się podmiotów. Sprawa Tagiyev i Huseynov przeciwko Azerbejdżanowi jest sprawą, w której doszło do kolizji wolności wypowiedzi i wolności wyznania.

Wolność wypowiedzi, w tym wolność wypowiedzi w prasie, jest jedną z niekwestionowanych podstaw ustrojowych państw demokratycznych. Nie można mówić o pełnej demokracji w państwach, w których wolność ta jest ograniczana $\mathrm{w}$ sposób uchybiający wypracowanym standardom praworządności. Również państwa aspirujące do miana demokratycznych mają tego świadomość, dlatego wolność wypowiedzi umieszczają w swych ustawach zasadniczych wśród wartości chronionych konstytucyjnie, przystępują do umów międzynarodowych, dobrowolnie przyjmując na siebie obowiązek respektowania tej wolności i na różnych forach

* Dr, Katolicki Uniwersytet Lubelski Jana Pawła II; e-mail: lidia.jaskula@kul.pl, https:/ / orcid.org/0000-0003-3619-5826. 
międzynarodowych deklarują przywiązanie do niej. We współczesnej Europie podstawowe odniesienie normatywne dla konstrukcji praw człowieka stanowi Konwencja o Ochronie Praw Człowieka i Podstawowych Wolności ${ }^{1}$, nazywana "konstytucyjnym instrumentem europejskiego porządku publicznego" ${ }^{2}$. Ireneusz C. Kamiński nazywa ją konwencją statutową, co w praktyce oznacza, że każde państwo członkowskie Rady Europy musi stać się jej stroną i poddać w całości jej mechanizmowi kontrolnemu ${ }^{3}$. Konwencja ustala katalog praw i wolności człowieka, a jedną z nich jest wolność wypowiedzi. Jednak - co również wynika bezpośrednio z przepisów prawa - wolność ta nie ma charakteru absolutnego i w praktyce życia społecznego jest konfrontowana z innymi wartościami, także chronionymi przez przepisy prawa. Jedną z takich wartości jest wolność wyznania ${ }^{4}$. Obie wolności są aspektami wolności człowieka, której ontycznym źródłem, akceptowanym i wskazywanym w wielu aktach prawnych kręgu kultury europejskiej, jest osobowa godność człowieka ${ }^{5}$. Obie wolności mają zatem to samo źródło i choć ich istota ma charakter pozaprawny, prawo reguluje zakres jednej i drugiej.

Analiza natury obu wartości - wolności wypowiedzi i wolności wyznania - prowadzi do wniosku, że w przypadku ich konfrontacji i przekroczenia granic wyznaczanych przez prawo konieczne jest chronienie jednej

1 Dz. U. z 1993 r. Nr 61, poz. 284 z późn. zm. (dalej: Konwencja lub EKPC).

2 I.C. Kamiński, Uprawnienia i obowiazki dziennikarskie w orzecznictwie Europejskiego Trybunału Praw Człowieka, w: Status prawny dziennikarza, red. W. Lis, Warszawa 2014, s. 99.

3 Por. tamże, s. 99.

4 Pojęciem „wolność wyznania” autorka obejmuje „wolność myśli, sumienia i wyznania”. Szerzej na temat „wolności myśli, sumienia i wyznania” w relacji do „wolności wypowiedzi": L.K. Jaskuła, Uczucia religijne jako granica wolności wypowiedzi (wybrane zagadnienia prawne), w: Praktyczne aspekty wolności wypowiedzi, red. W. Lis, Z. Husak, Torun 2011, s. $359-380$.

5 Chociaż EKPC nie wskazuje godności człowieka jako źródła praw i wolności expressis verbis, to wniosek taki uzasadnia treść preambuły Konwencji, która zawiera odwołanie do Powszechnej Deklaracji Praw Człowieka, przyjmującej godność jako źródło praw i wolności. Przekonanie takie może potwierdzać fakt, że pojęcie godności człowieka expressis verbis pojawia się preambule Protokołu nr 13 do EKPC. Podobnie zagadnienie przedstawia L. Garlicki: „Wstęp nie wymienia w sposób wyraźny zasady godności człowieka, co może o tyle dziwić, że Powszechna Deklaracja Praw Człowieka mówi o przyrodzonej godności człowieka oraz równych i niezbywalnych prawach wszystkich członków rodziny ludzkiej. Nadrobiono tę lukę dopiero w 2002 r., w preambule do Protokołu Nr 13", cyt. za: Wstęp, w: Konwencja o Ochronie Praw Człowieka i Podstawowych Wolności, t. 1. Komentarz do artykułów 1-18, red. L. Garlicki, Warszawa 2010 [baza danych Legalis]. 
przed drugą. Bez trudu możemy sobie wyobrazić sytuację, w której wymagane będzie chronienie wolności wyznania przed skutkami nadużycia wolności wypowiedzi (w szczególności, gdy będzie ona realizowana przy pomocy środków społecznego komunikowania), czy sytuację, w której ochrony będzie wymagała wolność wypowiedzi zagrożona przez działania wynikające z nadużywania wolności wyznania. Do takiego konfliktu doszło w sprawie Tagiyev i Huseynov v. Azerbejdżan, a wyrok ETPC z dnia 5 grudnia 2019 r. stanowi kolejną próbę ustalenia relacji między jedna i drugą. Powagi tej sprawie i jej rozstrzygnięciu dodaje fakt, że jeden z wnioskodawców skarżących państwo - stronę Konwencji, znany pisarz, felietonista i dziennikarz Rafig Tagiyev w czasie trwania procesu zmarł w wyniku zamachu na swoje życie. Mord był następstwem jego działalności dziennikarskiej ${ }^{6}$ i stał się przedmiotem licznych oficjalnych wystąpień, m.in. rezolucji Parlamentu Europejskiego w sprawie Azerbejdżanu ${ }^{7}$.

Wybrany temat artykułu, a więc zagadnienie kolizji wolności wypowiedzi z wolnością wyznania na kanwie wyroku ETPC w sprawie Tagiyev i Huseynov przeciwko Azerbejdżanowi zasługuje na opracowanie z kilku powodów: wyrok jest aktualnie najnowszym orzeczeniem ETPC $\mathrm{w}$ tym zakresie, nie był do tej pory przedmiotem analiz doktryny prawa oraz dotyczy głośnej sprawy uwięzienia znanego pisarza i publicysty, który z powodu swojej publikacji został nie tylko pozbawiony wolności, ale również zamordowany, a sam artykuł jest próbą ponownego przyjrzenia się kryteriom branym pod uwagę $\mathrm{w}$ rozstrzyganiu, której z wolności dać pierwszeństwo w przypadku ich kolizji. W tym celu, zdaniem Autorki, warto zaprezentować zarys normatywnych modeli jednej i drugiej wolności zawarty w EKPC i zestawić go z najnowszym przykładem orzekania ETPC w tym zakresie, w tym przypadku w sprawie Tagiyev i Huseynov v. Azerbejdżan. Autorka opracowania nie rości sobie prawa do formułowania definitywnych wniosków, tym bardziej, że nawet w świetle

6 Por. Reporters Without Borders, Worldwide round-up of journalists killed, detained, held hostage, or missing in 2019: A total of 49 journalists were killed this year, 389 are currently in prison and 57 are being held hostage, according to the annual worldwide round-up of deadly violence and abusive treatment against journalists, released today by Reporters Without Borders (RSF), https:/ / rsf.org/en/news/rsf-yearly-round-historically-low-number-journalists-killed-2019 [dostęp: 26.12.2019 r.].

7 Rezolucja Parlamentu Europejskiego z dnia 15 grudnia 2011 r. w sprawie Azerbejdżanu, zwłaszcza przypadku Rafiga Tagiego (2013/C 168 E/15), Dz. Urz. UE C z 14.06.2013, https:/ / sip.lex.pl/\#/ act/ 68332212 [dostęp: 3.01.2020 r.]. 
orzecznictwa ETPC ich ustalenie nie wydaje się możliwe. Opracowanie stanowi próbę przedstawienia pewnego punktu widzenia i zaproszenie do dyskusji na temat analizowanych zagadnień.

\section{Zarys normatywnego modelu wolności wypowiedzi zawartego w Konwencji o Ochronie Praw Człowieka i Podstawowych Wolności}

Konwencja o Ochronie Praw Człowieka i Podstawowych Wolności rysuje model wolności wypowiedzi, stanowiąc, że „Każdy ma prawo do wolności wyrażania opinii. Prawo to obejmuje wolność posiadania poglądów oraz otrzymywania i przekazywania informacji i idei bez ingerencji władz publicznych i bez względu na granice państwowe [... $]^{\prime 8}$. Interpretacja tak sformułowanego zakresu wolności wypowiedzi została wskazana w przywoływanym regularnie w orzecznictwie i doktrynie orzeczeniu ETPC w sprawie Handyside v. Wielka Brytania, w którym Trybunał podkreślił, że swoboda wypowiedzi jest jednym z filarów demokratycznego społeczeństwa, podstawą jego rozwoju i warunkiem rozwoju jednostki, kładąc jednocześnie nacisk na to, że nie może ona obejmować wyłącznie informacji i poglądów odbieranych przychylnie albo postrzeganych jako nieszkodliwe lub obojętne, ale odnosić się również do takich, które obrażają, oburzają lub wprowadzają niepokój w państwie albo w określonej grupie społeczeństwa, dodając, że takie są wymagania pluralizmu, tolerancji i otwartości, bez których demokratyczne społeczeństwo nie istnieje9 . Podejście to wyznaczyło bardzo konkretny, choć niekiedy budzący

8 Art. 10 EKPC: „1. Everyone has the right to freedom of expression. This right shall include freedom to hold opinions and to receive and impart information and ideas without interference by public authority and regardless of frontiers". Akt prawny w tym samym przepisie stanowi, że: „This Article shall not prevent States from requiring the licensing of broadcasting, television or cinemaenterprises", umożliwiając koncesjonowanie działalności tego typu.

9 Por. wyrok ETPC z dnia 7 grudnia 1976 r. w sprawie Handyside v. Wielka Brytania, § 49: „Freedom of expression constitutes one of the essential foundations of such a [democratic - L.J.] society, one of the basic conditions for its progress and for the development of every man. Subject to paragraph 2 of Article 10 (art. 10-2), it is applicable not only to «information» or «ideas» that are favourably received or regarded as inoffensive or as a matter of indifference, but also to those that offend, shock or disturb the State or any sector of the population. Such are the demands of that pluralism, tolerance and 
dyskusje, konsekwentnie prezentowany przez ETPC sposób interpretacji zakresu treści tej wolności. Jednak wolność wypowiedzi nie jest wolnością absolutną. Sędzia ETPC Luzius Wildhaber jednoznacznie stwierdził, że prawo do obrażania nie obejmuje mowy nienawiści czy nawoływania do przemocy ${ }^{10}$. Przepisy EKPC wskazują granice owej wolności, których przekroczenie sprawia, że wypowiedź przestaje korzystać z ochrony prawa. Treść przepisu ust. 2 art. 10 EKPC informuje o nierozerwalności wolności z obowiązkami oraz odpowiedzialnością i stanowi, że korzystanie z tych wolności może podlegać wymogom formalnym, warunkom, ograniczeniom i sankcjom, ale tylko takim, które są przewidziane przez prawo krajowe (prescribed by law) i niezbędne w społeczeństwie demokratycznym (necessary in a democratic society) dla ochrony wskazanych w tym przepisie wartości (pursue one or more legitimate aims). W doktrynie wskazuje się zatem trzy kryteria testowania wprowadzanych ograniczeń: legalności, konieczności i celowości ${ }^{11}$. Należy pamiętać, że przesłanka „niezbędności w społeczeństwie demokratycznym" wprowadza wyższy standard ochrony omawianej wolności niż przesłanka „niezbędności w ogóle” spotykana w innych aktach prawnych. Wartości, dla których ochrony może zostać ograniczona wolność wypowiedzi to wskazane enumeratywnie w art. 10 ust. 2 bezpieczeństwo państwowe, integralność terytorialna i bezpieczeństwo publiczne, zapobieganie zakłóceniu porządku lub przestępstwu, ochrona zdrowia lub moralności, ochrona dobrego imienia i praw innych osób, zapobieganie ujawnianiu informacji poufnych, zagwarantowanie powagi i bezstronności władzy sądowej ${ }^{12}$. Kategoria "praw innych osób”

broadmindedness without which there is no "democratic society»", http://hudoc.echr. coe.int/eng?i=001-57499 [dostęp: 29.12.2019 r.].

10 „But what does such a «right to offend» comprehend? It seems clear that it does not cover hate speech or incitement to violence", L. Wildhaber, The right to offend, shock or disturb? Aspects of freedom of expression under the European Convention of Human Rights, The Irish Jurist 2001, t. 36, s. 19.

11 Por. I.C. Kamiński, Ograniczenia swobody wypowiedzi dopuszczalne w Europejskiej Konwencji Praw Człowieka. Analiza krytyczna, Warszawa 2010, s. 43-44.

12 Art. 10 ust. 2 EKPC: "The exercise of these freedoms, since it carries with it duties and responsibilities, may be subject to such formalities, conditions, restrictions or penalties as are prescribed by law and are necessary in a democratic society, in the interests of national security, territorial integrity or public safety, for the prevention of disorder or crime, for the protection of health or morals, for the protection of the reputation or rights of others, for preventing the disclosure of information received in confidence, or for maintaining the authority and impartiality of the judiciary". 
w podanym katalogu teoretycznie mogła stanowić podstawę stwarzającą bardzo szeroki obszar dla uzasadniania przypadków bronienia się przed nadużyciami wolności wypowiedzi, w praktyce tak się jednak nie stało państwa członkowskie nie mogą "łatwo” powoływać się na ograniczenia wolności wypowiedzi przewidziane przez Konwencję, ponieważ punktem wyjścia każdej wykładni powinno być założenie dominującej pozycji swobody wypowiedzi ${ }^{13}$. Warto także przypomnieć, że przytoczone regulacje odnoszą się do wolności wypowiedzi obejmującej wszystkie jej formy, a więc również wypowiedzi w prasie. Możemy zatem przyjąć, że także do wolności prasy, rozumianej zarówno jako wolność prasowej działalności wydawniczej, jak i wolność działalności dziennikarskiej ${ }^{14}$, odnosimy na gruncie art. 10 EKPC wszystkie wskazane w nim aspekty wolności wypowiedzi (freedom of expression): wolność wyrażania opinii, wolność posiadania poglądów, otrzymywania i przekazywania informacji i idei bez ingerencji władz publicznych i bez względu na granice państwowe, pamiętając, że przepisy prawa ustawiają także jej granice.

Wolna prasa pełni różne funkcje: pełniąc funkcję informacyjną, jest nośnikiem informacji i opinii, a realizując jednocześnie funkcję kontrolną, dba o to, aby żadna z istniejących władz nie nadużywała swoich kompetencji. Warunkiem tak pojmowanej wolności prasy jest niezależność dziennikarzy ${ }^{15}$. Zdaniem J. Sobczaka niezależność tę pojmowano w pierwszym rzędzie jako niezwiązanie z żadną władzą i z żadnym urzędem, co miało być gwarancją obiektywizmu i bezstronności prasy - jakiekolwiek związki instytucjonalne prasy z którąkolwiek z konstytucyjnie wyróżnionych władz przeczą w zasadzie jej wolności, podobnie jak zaprzeczeniem tej wolności jest także bezprawne wpływanie przez władze wykonawcze na treść przekazu ${ }^{16}$. Wyznaczanie przez prawo i orzecznictwo granic wolności wypowiedzi w praktyce jest zadaniem trudnym. Robiąc to, należy pamiętać, by nie naruszyć istoty wolności, która jest poddawana ograniczeniom. Za szerokim określeniem granic wolności wypowiedzi przemawiają nadrzędne wartości, jakim ma ona służyć: prawo do wymiany poglądów,

13 Por. I.C. Kamiński, Media w europejskiej konwencji o ochronie praw człowieka i podstawowych wolności, w: Prawo mediów, red. J. Barta, R. Markiewicz, A. Matlak, Warszawa 2008, s. 39-40.

14 Por. L.K. Jaskuła, Prawo do dobrego imienia a wolność prasy, Warszawa 2008, s. 45.

15 Por. J. Sobczak, Zawód dziennikarza w optyce Europejskiego Trybunału Praw Człowieka. Między idealistycznym a realistycznym paradygmatem wolności prasy, w: Status prawny..., s. 61.

16 Por. tamże. 
opinii i idei, prawo do informowania innych i otrzymywania informacji ${ }^{17}$. Należy również pamiętać, że w doktrynie podkreśla się, iż granice wolności wypowiedzi uzależnione są od strefy, której ona dotyczy, przy czym granice szersze dopuszczone są $\mathrm{w}$ wypowiedziach dotyczących spraw publicznych, co służy właściwemu funkcjonowaniu systemów demokratycznych, bo otrzymywanie różnorodnych opinii na tematy publiczne, szczególnie opinii krytycznych, umożliwia demokratycznemu społeczeństwu kontrolowanie władzy ${ }^{18}$.

Wypada w tym miejscu podkreślić, że na przestrzeni lat, przy niezmienionym brzmieniu art. 10 EKPC, orzecznictwo ETPC dotyczące wolności wypowiedzi, w tym wolności prasy, przeszło ewolucję, której nie wolno pominąć, podejmując próbę wskazania w sposób zwięzły kluczowych cech normatywnego modelu tej wolności ${ }^{19}$. Ireneusz C. Kamiński wskazuje, że efektem formacyjnego dla art. 10 EKPC orzecznictwa, pochodzącego $\mathrm{z}$ lat 70. i 80. XX w., zaostrzonego w latach 90., była szeroka i daleko idąca ochrona wolności prasy, mediów i dziennikarzy, co wynikało z faktu, że Trybunał nadał kluczową rangę wypowiedziom politycznym i dotyczącym ważnych zagadnień publicznych, rzadko godząc się na krajową ingerencję, oraz że mediom i dziennikarzom powierzył zadanie publicznego kontrolera (public watchdog), pośrednika i komentatora kształtującego wiedzę i opinię społeczeństwa ${ }^{20}$. Autor ten zwrócił uwagę również na fakt, że wówczas

oznajmiając konwencyjny standard Trybunał nie odwoływał się do porównawczej analizy rozwiązań krajowych, lecz abstrahował od nich, posługując się argumentacją zasadniczą. To z określonych założeń charakteryzujących demokratyczne społeczeństwo miały wynikać w konieczny, autonomiczny sposób - niczym z aksjomatów - identyfikowane reguły. W konsekwencji Trybunał mógł zignorować istnienie $\mathrm{w}$ krajowych porządkach prawnych rozwiązań dalekich od oznajmianego standardu. Więcej, takie rozwiązania prawne, nawet gdy były powtarzane $\mathrm{w}$ poszczególnych krajach, stawały się w świetle konwencyjnego standardu normatywną anomalią. W świetle

17 Por. tamże, s. 65.

18 Por. tamże.

19 J. Sobczak, Swoboda wypowiedzi w orzecznictwie Trybunału Praw Człowieka w Strasburgu. Część I, Ius Novum 2007, nr 2-3, s. 5-38; tenże, Swoboda wypowiedzi w orzecznictwie Trybunału Praw Człowieka w Strasburgu. Część II, Ius Novum 2007, nr 4, s. 5-43; J. Taczkowska-Olszewska, Racjonalizacja wolności prasy - od modelu absolutnego do warunkowego. Europejski $i$ krajowy kontekst wykładni prawa, Przegląd Sejmowy 2018, nr 1, s. 122-131.

20 Tak: I.C. Kamiński, Uprawnienia i obowiązi dziennikarskie..., s. 100-101. 
strasburskiego standardu normatywnego znaczenia pozbawiana była zawarta w art. 10 EKPC formuła mówiąca o obowiązkach i odpowiedzialności ${ }^{21}$.

Ten sposób orzekania budził niekiedy krytykę, zgodnie z którą Trybunał uczynił z wolności słowa „superwolność”, co miało dokonywać się kosztem innych wolności ${ }^{22}$. W literaturze przedmiotu przyjmuje się, że dominował wtedy idealistyczny paradygmat wolności prasy, zmierzający wręcz do jej absolutyzacji ${ }^{23}$. W orzecznictwie od początku XXI w. dostrzega się jednak odchodzenie od paradygmatu idealistycznego w stronę paradygmatu realistycznego, wiążąc zakres wolności prasy z realizacją przez dziennikarzy wymogów rzetelności, staranności i etyczności, a więc z realizacją kryteriów sztuki dziennikarskiej (dobrego dziennikarstwa), prowadzącą do powstawania godnej informacji ${ }^{24}$. W literaturze mówi się o konstrukcji triady obowiązków dobrej roboty dziennikarskiej ${ }^{25}$. Na zmianę modelu wolności prasy - jako pierwszy - zwrócił uwagę sędzia ETPC Franz Matscher, sygnalizując odejście od idealistycznego i przejście do realistycznego modelu ochrony wolności prasy ${ }^{26}$. Podobnie sędzia Luzius Wildhaber zwrócił uwagę na fakt, że należy z ostrożnością podchodzić do dawania pierwszeństwa wolności wypowiedzi prasowej, gdyż potencjalnie dewastujący efekt wypowiedzi publicznych, wynikający z olbrzymiej siły oddziaływania i natychmiastowego charakteru przekazu nowoczesnych mediów, wzmacnia obowiązki i odpowiedzialność tworzących te media; zmiana charakteru części mediów z będących nośnikiem idei służących rozwojowi demokracji na instrumenty zarabiania pieniędzy być może wpłynie na sposób orzekania przez ETPC w sytuacji ważenia i dawania pierwszeństwa określonej wolności w przypadku kolizji wolności prasy z innymi wolnościami ${ }^{27}$.

21 Tamże, s. 101.

22 Tamże.

${ }^{23}$ Por. J. Sobczak, Zawód dziennikarza w optyce Europejskiego Trybunatu Praw Człowieka..., s. 71.

24 Por. I.C. Kamiński, Uprawnienia i obowiązki dziennikarskie..., s. 102-103.

25 Por. J. Skrzydło, Wolność słowa w orzecznictwie Sądu Najwyższego Stanów Zjednoczonych i Europejskiego Trybunatu Praw Człowieka. Analiza porównawcza, Torun 2013, s. 573.

26 F. Matscher, Idéalisme et réalisme dans la jurisprudence de la Cour européenne des droits de l'homme, w: Protection des droits de l'homme: le perspective européenne, Protecting Human Rights: The European perspective. Studies in memory of Rolv Ryssdal, red. F. Matscher, H. Petzold, L. Wildhaber, Köln 2000, cyt. za: I.C. Kamiński, Ograniczenia swobody wypowiedzi..., s. 815.

27 Por. L. Wildhaber, The right to offend, shock or disturb..., s. 31. 
Mając świadomość, że prawo do swobody wypowiedzi nie jest nieograniczone i że granicą jego wykonywania są m.in.: prawa innych osób do wolności przed agresją w dziedzinie przekonań w sprawach wiary ${ }^{28}$, możemy podjąć się próby zarysowania normatywnego modelu wolności wyznania.

\section{Zarys normatywnego modelu wolności wyznania zawartego w Konwencji o Ochronie Praw Człowieka i Podstawowych Wolności}

Na gruncie EKPC regulacje dotyczące ochrony wolności wyznania zostały zawarte $\mathrm{w}$ art. 9 EKPC zatytułowanym „Wolność myśli, sumienia i wyznania" 29 . Zgodnie z treścią tego przepisu każdy ma prawo do wolności myśli, sumienia i wyznania. Prawo to obejmuje wolność zmiany wyznania lub przekonań oraz wolność uzewnętrzniania indywidualnie lub wspólnie z innymi, publicznie lub prywatnie swego wyznania lub przekonań przez uprawianie kultu, nauczanie, praktykowanie i czynności rytualne. Wolność ta podlega ograniczeniom tylko w jednym aspekcie - $\mathrm{w}$ przestrzeni uzewnętrzniania wyznania lub przekonań. Tylko ten aspekt wolności może podlegać ograniczeniom i jedynie takim, które są przewidziane przez ustawę i konieczne w społeczeństwie demokratycznym z uwagi na interesy bezpieczeństwa publicznego, ochronę porządku publicznego, zdrowia i moralności lub ochronę praw i wolności innych osób $^{30}$. Ograniczenia powinny zatem, zgodnie z art. 9 ust. 2 EKPC, przejść

28 Por. A. Wąsek, Przestępstwa przeciwko przekonaniom religijnym de lege lata $i$ de lege ferenda, Państwo i Prawo 1995, z. 7, s. 38; tenże, Ochrona uczuć religijnych w prawie karnym, w: Prawo wyznaniowe III Rzeczypospolitej, red. H. Misztal, Lublin-Sandomierz 1999, s. 77.

29 Zakres i treści tej wolności szeroko, na co nie pozwalają ramy artykułu, omawiają m.in: M. Sobczak, Wolność sumienia i wyznania, jej gwarancje w systemie prawnym Rady Europy oraz w orzecznictwie Europejskiego Trybunatu Praw Człowieka w Strasburgu, Ius Novum 2008, nr 3, s. 87-116; J. Falski, Symbolika i przekonania religijne w miejscu pracy (na tle wyroku Europejskiego Trybunału Praw Człowieka w sprawie Eweida i inni v. Wielka Brytania), Państwo i Prawo 2015, z. 8, s. 77-90; M. Wółkowska, Prawa kulturalne w Europejskiej Konwencji Praw Człowieka. Analiza w oparciu o orzecznictwo Europejskiego Trybunatu Praw Człowieka w Strasburgu, Studia Iuridica Toruniensia 2013, t. 13, s. 241-260; L. Garlicki, Artykuł 9 EKPC, w: Konwencja..., t. 1. Komentarz...

30 Por. art. 9: „Freedom of thought, conscience and religion 1. Everyone has the right to freedom of thought, conscience and religion; this right includes freedom to change his 
pozytywnie test trzech kryteriów, analogiczny do testu z art. 10 Konwencji: legalności, konieczności oraz celowości ${ }^{31}$.

Myśl tę rozwija I.C. Kamiński, dodając, że art. 9 EKPC zezwala na dokonywanie ograniczeń tylko w odniesieniu do wolności uzewnętrzniania wyznania i przekonań, czyli w obszarze identyfikowanym jako tzw. forum externum, przypominając, że istnieje tym samym również „sfera wewnętrzna", forum internum, związana z posiadaniem poglądów oraz ich modyfikacją (obejmującą także ich porzucenie), która musi pozostać wolna od jakiejkolwiek ingerencji, a każde ograniczenie „wolności wewnętrznej" jest ex definitione sprzeczne z Konwencją ${ }^{32}$. Jak łatwo zauważyć, Konwencja w swej treści chroni wolność wyznania w sposób jednoznaczny, zdecydowany i szeroki, w wymiarze wewnętrznym w sposób absolutny, w wymiarze zewnętrznym w sposób dopuszczający ograniczenia. Koresponduje to $\mathrm{w}$ pewnym sensie $\mathrm{z}$ konsekwentnie prezentowanym na temat tej wolności stanowiskiem Kościoła katolickiego - w nauczaniu społecznym i wypowiedziach kolejnych papieży. Jan Paweł II w „Liście apostolskim o wolności religijnej” pisał, że „Wolność sumienia i religii jest [...] pierwszym i niezbędnym prawem osoby ludzkiej; a [...] w stopniu jakim dotyka najbardziej intymnej sfery ducha, podtrzymuje głęboko zakotwiczoną w każdej osobie rację bytu innych wolności"33.

Jak podkreśla I.C. Kamiński, problematyka dotycząca ochrony wolności wyznania trafiła do ETPC dużo później niż problematyka dotycząca ochrony wolności wypowiedzi ${ }^{34}$. W doktrynie przyjmuje się, że orzecze-

religion or belief and freedom, either alone or in community with others and in public or private, to manifest his religion or belief, in worship, teaching, practice and observance. 2. Freedom to manifest one's religion or beliefs shall be subject only to such limitations as are prescribed by law and are necessary in a democratic society in the interests of public safety, for the protection of public order, health or morals, or for the protection of the rights and freedoms of others".

31 Por. A. Wiśniewski, O symbolach religijnych w orzecznictwie strasburskim, Gdańskie Studia Prawnicze 2013, t. 29, s. 261.

32 Por. I.C. Kamiński, Wolność religijna a jednostka, w: Prawne granice sumienia i wyznania, red. J. Kondratiewa-Bryzik, R. Wieruszewski, M. Wyrzykowski, 2012 [wyd. el. LEX]. Na ten temat również szeroko: L. Garlicki, Artykuł 9 EKPC, w: Konwencja..., t. 1. Komentarz...

33 Jan Paweł II, List apostolski z 1.09.1980 r. o wolności religijnej (L'eglise Catholique), http://www.apostol.pl/janpawelii/listy-apostolskie/o-wolno\% C5\%9Bci-religijnej-leglise-catholique [dostęp: 30.12.2019 r.].

34 Por. I.C. Kamiński, Wolność religijna a jednostka..., https://sip.lex.pl/\#/monograph/369240090/201932 [dostęp: 30.12.2019 r.]. 
niem formacyjnym dla wolności sumienia i wyznania jest wyrok Kokkinakis v. Grecja ${ }^{35}$. W § 31 orzeczenia ustalono, że wolność myśli, sumienia i wyznania jest - jak zagwarantowano w art. 9 Konwencji - jednym z fundamentów "społeczeństwa demokratycznego" w rozumieniu Konwencji i stanowi, w jej wymiarze religijnym, jeden z najistotniejszych elementów, które składają się na tożsamość wierzących i ich koncepcję życia, ale jest również cenna dla ateistów, agnostyków, sceptyków i osób niezainteresowanych religią czy obojętnych na sprawy religii. Od niej zależy pluralizm nierozerwalnie związany z demokratycznym społeczeństwem, o który walczono przez wieki. Trybunał podkreślił, że chociaż wolność religijna jest przede wszystkim kwestią jednostki, indywidualnego sumienia, realizuje się również m.in. przez wolność do „manifestowania [swojej] religii". Składanie świadectw słowami i czynami wiąże się z istnieniem przekonań religijnych. Zgodnie z art. 9 wolność wyrażania swojej religii jest realizowana nie tylko we wspólnocie z innymi, "publicznie” i w kręgu tych, którzy dane wyznanie podzielają, ale może być również realizowana "samodzielnie” i „prywatnie”. Sędziowie wskazali, że wolność wyrażania poglądów religijnych obejmuje m.in. prawo do przekonywania innych o słuszności własnej religii. Bez tej możliwości prawo do zmiany religii lub przekonań pozostałoby martwą literą ${ }^{36}$. Trybunał jednak dodał również, że w demokratycznych społeczeństwach w ramach jednej populacji funkcjonują wyznający różne religie i mający różne przekonania.

35 Wyrok ETPC z dnia 25 maja 1993 r. w sprawie Kokkinakis v. Grecja, http:/ / hudoc. echr.coe.int/eng?i=001-57827 [dostęp: 30.12 .2019 r.].

36 Por. Tamże, § 31: „As enshrined in Article 9 (art. 9), freedom of thought, conscience and religion is one of the foundations of a «democratic society» within the meaning of the Convention. It is, in its religious dimension, one of the most vital elements that go to make up the identity of believers and their conception of life, but it is also a precious asset for atheists, agnostics, sceptics and the unconcerned. The pluralism indissociable from a democratic society, which has been dearly won over the centuries, depends on it. While religious freedom is primarily a matter of individual conscience, it also implies, inter alia, freedom to «manifest [one's] religion» Bearing witness in words and deeds is bound up with the existence of religious convictions. According to Article 9, freedom to manifest one's religion is not only exercisable in community with others, «in public» and within the circle of those whose faith one shares, but can also be asserted «alone» and «in private» furthermore, it includes in principle the right to try to convince one's neighbour, for example through «teaching» failing which, moreover, «freedom to change [one's] religion or belief» enshrined in Article 9 (art. 9), would be likely to remain a dead letter". 
Aby zapewnić ich spokojne współistnienie, państwa mogą nałożyć pewne ograniczenia na sposób uzewnętrzniania przekonań ${ }^{37}$.

Tezy sformułowane w orzeczeniu Kokkinakis v. Grecja zostały przywołane w kolejnym ważnym orzeczeniu dotyczącym ochrony wolności wyznania - w sprawie Otto-Preminger-Institut v. Austria, która dotyczyła zajęcia kopii filmu naruszającego, w ocenie sądu krajowego, uczucia religijnych osób wierzących (katolików) ${ }^{38}$. ETPC orzekł w tej sprawie brak naruszenia art. 10 EKPC, ale jednocześnie wprowadził kolejne istotne twierdzenia dotyczące ochrony wolności wyznania. Stwierdził mianowicie, że osoby, które decydują się na korzystanie ze swobody wyznania, niezależnie od tego, czy robią to jako członkowie większości religijnej czy mniejszości, nie mogą racjonalnie oczekiwać braku jakiejkolwiek krytyki ze strony innych. Muszą tolerować i akceptować zaprzeczanie przez innych ich wierzeń religijnych, a nawet propagowanie przez innych poglądów czy doktryn wrogich ich wierze ${ }^{39}$. Odpowiedzialnością państwa jest zapewnienie wyznawcom możliwości korzystania z wolności przekonań religijnych w sytuacjach negowania czy krytykowania ich przekonań. Jeśli jest to zagrożone, władze mają możliwość uznać za konieczne podjęcie środków represjonujących niektóre zachowania. Interwencja może polegać np. na nałożeniu ograniczeń na przekaz informacji i poglądów, jeśli są one nie do pogodzenia z poszanowaniem swobody przekonań. Stanie się tak, gdy dojdzie do prowokacyjnego przedstawienia przedmiotów religijnej czci. Postępowanie takie bowiem, zdaniem Trybunału, stanowi złośliwe naruszenie ducha tolerancji, który jest cechą demokratycznego społeczeństwa ${ }^{40}$.

37 Por. tamże, § 33: „The fundamental nature of the rights guaranteed in Article 9 [...] is also reflected in the wording of the paragraph providing for limitations on them. [...] Article 9 (art. 9-1) refers only to «freedom to manifest one's religion or belief». In so doing, it recognises that in democratic societies, in which several religions coexist within one and the same population, it may be necessary to place restrictions on this freedom in order to reconcile the interests of the various groups and ensure that everyone's beliefs are respected".

38 Wyrok ETPC z dnia 20 września 1994 r. w sprawie Otto-Preminger-Institut v. Austria, http:/ / hudoc.echr.coe.int/eng?i=001-57897 [dostęp: 30.12 .2019 r.].

39 Por. tamże, § 47: „Those who choose to exercise the freedom to manifest their religion, irrespective of whether they do so as members of a religious majority or a minority, cannot reasonably expect to be exempt from all criticism. They must tolerate and accept the denial by others of their religious beliefs and even the propagation by others of doctrines hostile to their faith".

40 Por. tamże, § 47: „However, the manner in which religious beliefs and doctrines are opposed or denied is a matter which may engage the responsibility of the State, notably 
Mimo kolejnych lat orzekania ETPC strasburski standard ochrony na mocy art. 9 EKPC ciągle się kształtuje. Orzeczenia ETPC z tego obszaru nie charakteryzują się jeszcze stabilnością, jakiej moglibyśmy oczekiwać po czasie, który upłynął od pierwszych orzeczeń formujących. Orzekanie w tym zakresie dodatkowo komplikuje fakt, że rośnie liczba spraw jak sprawa Tagiyev i Huseynov - pochodzących z państw, które choć są członkami Rady Europy, swoje ustroje budują na odmiennym od europejskiego systemie wartości.

\section{Okoliczności sprawy Tagiyev i Huseynov oraz orzeczenia krajowe}

Wnioskodawcy w sprawie Tagiyev i Huseynov v. Azerbejdżan batalię o ochronę swoich praw przed ETPC rozpoczęli w 2008 r. Skargę wniesioną przez dwóch obywateli Azerbejdżanu poprzedziły wydarzenia, które stały się jej podstawą faktyczną.

Dnia 1 listopada 2006 r. Rafig Naziraoglu Tagiyev (Rafiq Nazir oğlu Tağıyeva - "pierwszy skarżący”) na łamach czasopisma "Senat Gazeti” („,Art Newspaper") opublikował pod pseudonimem Rafig Tagi artykuł zatytułowany Europa $i$ my. Autor artykułu ${ }^{41}$, znany pisarz i felietonista, współpracujący z różnymi tytułami prasowymi, poruszał w nim kwestie relacji między chrześcijaństwem i islamem oraz umieścił w nim stwierdzenia, które następnie zostały uznane za naruszające obowiązujące

its responsibility to ensure the peaceful enjoyment of the right guaranteed under Article 9 (art. 9) to the holders of those beliefs and doctrines. Indeed, in extreme cases the effect of particular methods of opposing or denying religious beliefs can be such as to inhibit those who hold such beliefs from exercising their freedom to hold and express them. In the Kokkinakis judgment the Court held, in the context of Article 9 (art. 9), that a State may legitimately consider it necessary to take measures aimed at repressing certain forms of conduct, including the imparting of information and ideas, judged incompatible with the respect for the freedom of thought, conscience and religion of others [...]. The respect for the religious feelings of believers as guaranteed in Article 9 (art. 9) can legitimately be thought to have been violated by provocative portrayals of objects of religious veneration; and such portrayals can be regarded as malicious violation of the spirit of tolerance, which must also be a feature of democratic society".

${ }^{41}$ Cały tekst przedmiotowego artykułu prasowego jest przytoczony w tłumaczeniu w: wyrok ETPC z dnia 5 grudnia 2019 r. w sprawie Tagiyev i Huseynov v. Azerbejdżan, § 8, http:/ / hudoc.echr.coe.int/eng?i=001-198705 [dostęp: 31.12.2019 r.]. 
w Azerbejdżanie przepisy prawa. Artykuł ukazał się w dwutygodniku, który zajmował się zagadnieniami związanymi ze sztuką, literaturą oraz teatrem i był publikowany w nakładzie około 800 egzemplarzy. Redaktorem naczelnym gazety $\mathrm{w}$ tym czasie był Samir Sadagat oglu Huseynov (Samir Sadaqat oğlu Hüseynov).

Po opublikowaniu artykułu skarżący byli publicznie ostro krytykowani przez przedstawicieli azerskich i irańskich grup religijnych, a jeden z przywódców religijnych Iranu, ajatollah Muhammad Fazel Lankarani, wydał na nich fatwę wzywającą do ich uśmiercenia. Publikacja tego artykułu wywołała również protesty w Azerbejdżanie i Iranie.

Dnia 11 listopada 2006 r. przeciwko autorowi artykułu prasowego i redaktorowi naczelnemu wszczęto postępowanie karne, powołując się na przepis art. 283 kodeksu karnego Azerbejdżanu, penalizujący m.in. nawoływanie do nienawiści lub wrogości etnicznej, rasowej, społecznej lub religijnej. Dziennikarza i redaktora naczelnego aresztowano ${ }^{42}$. Prowadzący

${ }^{42}$ Mimo że ramy artykułu nie pozwalają na szczegółowe przedstawienie tego zagadnienia, konieczne wydaje się poświęcenie kilku zdań sytuacji mediów w Azerbejdżanie. Jest ona bowiem realnym testem stanu demokracji w kraju, który przystępując w $2001 \mathrm{r}$. do Rady Europy, zobowiązał się do respektowania demokratycznych standardów europejskich. Jest wiedzą powszechną, że obecność Azerbejdżanu (i kilku innych państw) w Radzie Europy jest przedmiotem dyskusji i sprzeciwu wielu podmiotów (m.in. organizacji pozarządowych), z uwagi na fakt, że kraj ten nie tylko nie realizuje standardów europejskich, ale nagminnie je łamie. Azerbejdżan należy do czołówki państw skarżonych do ETPC - według danych na koniec 2018 r. z Azerbejdżanu pochodziło 2050 zawisłych skarg, co stanowi 3,6\% wszystkich skarg zawisłych na koniec 2018 r. (6. miejsce), zob. Pełnomocnik Ministra Spraw Zagranicznych ds. postępowań przed Europejskim Trybunałem Praw Człowieka, Raport z wykonania wyroków Europejskiego Trybunału Praw Człowieka przez Polskę za 2018 rok, Warszawa 2019, s. 39, https:/ /www.sw.gov.pl/assets/66/58 /71/9daae6481ba6c151aece0468936a7bd587ae36c8.pdf [dostęp: 31.12.2019 r.].

Aresztowania dziennikarzy nie należą do sytuacji wyjątkowych. Helsińska Fundacja Praw Człowieka (HFPC) zwróciła na ten stan rzeczy uwagę w apelu skierowanym do Komitetu Ministrów Rady Europy. Organizacja ta wskazywała na brak wykonania przez Azerbejdżan zobowiązań wynikających z wyroków Europejskiego Trybunału Praw Człowieka dotyczących skazywania dziennikarzy na wieloletnie kary pozbawienia wolności. W dokumencie podkreślono, że „pomimo deklaracji władz, że będzie podejmowała działania na rzecz wzmocnienia ochrony wolności słowa, sytuacja dziennikarzy w kraju drastycznie się pogorszyła w ostatnim czasie. [...] W ostatnim roku doszło do kolejnych aresztowań i orzeczeń skazujących dziennikarzy i blogerów poruszających tematy niewygodne dla reżimu. Za przykład może posłużyć skazanie na dwa lata kary pozbawienia wolności vlogera Mehmana Huseynova czy też utrzymywanie zakazu opuszczania kraju wobec 
sprawę śledczy zlecił ocenę tekstu opublikowanego artykułu pod kątem lingwistycznym i religijnym. W roli eksperta przedmiotową ocenę przeprowadził urzędnik departamentu wiedzy religijnej w Państwowym Komitecie ds. Współpracy z Organizacjami Religijnymi. Śledczy w szczególności zalecił ekspertowi ustalenie, czy artykuł Europa i my zawiera elementy, które mogą prowadzić do podżegania do nienawiści religijnej i wrogości, a jeśli tak, polecił ich wskazanie. Urzędnik wskazał cztery passusy artykułu, w których w jego ocenie dziennikarz naruszył prawo, w brzmieniu:

1. „Europa zawsze odrzucała i odrzuca kłamliwe humanistyczne idee innych religii, w tym islamu. Moralność w islamie jest aktem żonglowania; jego humanizm nie jest przekonujący”; 2. „w porównaniu z Jezusem Chrystusem, ojciec wojny, Prorok Mahomet jest po prostu przerażającym stworzeniem”; 3. „W najlepszym razie islam w Europie rozwijałby się małymi krokami demograficznymi. A może byłby kraj, w którym islam byłby reprezentowany przez kilka osób lub terrorystów żyjących incognito"; 4. „Europejski filozof nie działa jak klaun, jak robi to filozof wschodni, nie jest skłonny do sufizmu, szaleństwa, głupoty. Tak, wschodni filozof jest czystym aktorem; wszystkie jego działania są ozdobione wyobraźnią miniaturowego ornamentu ze względu na ideologię. Wschodni filozof mówi coś, żeby coś powiedzieć. Cel, droga jest nieznana lub całkiem abstrakcyjna".

W podsumowaniu urzędnik stwierdził, że artykuł ma na celu szerzenie nienawiści i wrogości wobec islamu oraz że istnieją wystarczające

dziennikarki Khadijy Ismayilovej, która w więzieniu spędziła ponad rok. Pomimo wcześniejszych zapowiedzi Azerbejdżan nie zniósł odpowiedzialności karnej za zniesławienie. Ponadto w marcu 2017 r. przyjęto surowsze regulacje, które ułatwiają cenzurowanie Internetu i prasy przez możliwość zablokowania stron internetowych, w razie gdy znajdą się na nich między innymi treści o charakterze terrorystycznym, zniesławiające lub naruszające prawa autorskie. Po wprowadzeniu ustawy władze zablokowały na stałe główne portale informacyjne, takie jak Azadliq.info, Meydan TV, Azerbaycan Saati, Turan TV i Azadliq. org", Helsińska Fundacja Praw Człowieka, Wolność mediów w Azerbejdżanie - apel do Komitetu Ministrów Rady Europy, 25.01.2018 r., http://www.hfhr.pl/wolnosc-mediow-w-azerbejdzanie-apel-do-komitetu-ministrow-rady-europy/ [dostęp: 31.12.2019 r.].

Na problem od lat zwracają uwagę także dysydenci z Azerbejdżanu: „Kierująca Instytutem na rzecz Pokoju i Demokracji Lejla Junus wytyka od lat rządom Alijewów nadużycia władzy, fałszowanie wyborów, tłumienie wolności słowa, brutalność policji, prześladowania opozycji, niewolenie więźniów politycznych", W. Jagielski, Niedemokratyczny Azerbejdżan przewodzi Radzie Europy, Depesza PAP z 1.06.2014 r., https://www.prawo. $\mathrm{pl} /$ prawnicy-sady/niedemokratyczny-azerbejdzan-przewodzi-radzie-europy,56297.html [dostęp: 31.12.2019 r.]. 
podstawy, aby stwierdzić istnienie $\mathrm{w}$ nim elementów prowadzących do podżegania do nienawiści i wrogości religijnej. Sąd orzekający w pierwszej instancji przyjął wnioski raportu jako decydujące w sprawie i opierając się na nich, nie dokonując żadnej oceny prawnej raportu, wydał wyrok skazujący Tagiyeva na trzy lata bezwzględnego pozbawienia wolności, a Huseynova na cztery lata tej samej kary ${ }^{43}$. Sądy apelacyjny i najwyższy podtrzymały wyrok sądu pierwszej instancji. Takie procedowanie z oczywistych względów jest niedopuszczalne w systemach demokratycznych, a wydawane $\mathrm{w}$ jego wyniku orzeczenia powinny być usuwane $\mathrm{z}$ obrotu prawnego. Tak się jednak nie stało $\mathrm{w}$ tym przypadku. Uwięzieni dziennikarz i redaktor naczelny po ponad roku spędzonym w więzieniu zostali zwolnieni na podstawie prezydenckiego prawa łaski. W 2008 r. wnieśli skargę do ETPC. Pod koniec 2011 r. pisarz i felietonista Rafig Naziraoglu Tagiyev stał się celem zamachu, który był spowodowany jego działalnością dziennikarską, i zmarł w wyniku odniesionych obrażeń.

\section{Stanowisko ETPC w sprawie Tagiyev i Huseynov v. Azerbejdżan - kontynuacja czy przełom $\mathrm{w}$ orzekaniu?}

Wnosząc skargę, Tagiyev i Huseynov podnieśli, że skazanie ich za publikację kwestionowanego artykułu stanowiło naruszenie ich praw chronionych przez Konwencję na podstawie art. 7, 9 i 10 EKPC ${ }^{44}$. Uwzględniając okoliczności sprawy, Trybunał stwierdził, że wniesiona skarga nie porusza odrębnych zagadnień na podstawie art. 7 i 9 EKPC i wszystkie

43 Wyrok ETPC z dnia 5 grudnia 2019 r. w sprawie Tagiyev i Huseynov v. Azerbejdżan, § 22: "Article 283: Incitement to ethnic, racial, social or religious hatred and hostility. 283.1. Acts aimed at inciting ethnic, racial, social or religious hatred and hostility, humiliation of national dignity, as well as acts aimed at restricting citizens' rights or establishing citizens' superiority on the basis of their ethnic, racial, social or religious origin, if committed openly or by means of the mass media, are punishable by a fine in the amount of one thousand to two thousand manats, or restriction of liberty for a period of up to three years, or deprivation of liberty for a period of two to four years. 283.2. The same acts, if committed: 283.2.1. with the use of violence or the threat of use of violence; 283.2.2. by a person using his official position; 283.2.3. by an organised group; are punishable by deprivation of liberty for a period of three to five years $[\ldots]^{\prime \prime}$.

${ }^{44}$ Por. tamże, § 25. 
one zostaną rozpatrzone na podstawie art. 10 Konwencji. Jednocześnie ETPC ustalił, że postępowanie $w$ tej sprawie przed Trybunałem dotyczy wyważenia sprzecznych interesów w korzystaniu z dwóch podstawowych wolności, a mianowicie prawa skarżących do przekazywania opinii publicznej swoich poglądów na temat religii w prasie z jednej strony oraz prawa innych do poszanowania ich wolności myśli, sumienia i wyznania $\mathrm{z}$ drugiej strony ${ }^{45}$.

W swoim wniosku skarżący podnieśli trzy zasadnicze kwestie. Po pierwsze argumentowali, że skazanie ich za popełnienie przestępstwa nawoływania do nienawiści religijnej i wrogości nie zostało wykazane przez sądy krajowe, które oparły się na raporcie urzędnika administracji oraz że przedmiotowy artykuł nie stanowił podżegania do nienawiści religijnej i wrogości, a próbował jedynie dokonać porównania islamu i chrześcijaństwa w kontekście europejskich i wschodnich wartości humanistycznych i koncepcji praw człowieka. W szczególności wnioskodawcy zwracali uwagę na to, że artykułu nie kierowano do żadnej grupy religijnej i nie było intencją autora podsycanie nienawiści i wrogości między jakimikolwiek grupami religijnymi ${ }^{46}$. Skarżący podnieśli również, że rozstrzygając tę sprawę, Trybunał powinien uwzględnić jej kontekst, ponieważ zarówno przed, jak i po publikacji nie doszło do ujawnienia się wrogości między grupami religijnymi w Azerbejdżanie. Po drugie podkreślono, że autor artykułu, będąc pisarzem bez jakiejkolwiek przynależności politycznej, nie wpływał swoją twórczością na żadną grupę społeczną czy religijną w kraju, a sam artykuł został opublikowany w gazecie o niskim nakładzie (około 800 egzemplarzy), z bardzo ograniczonym wpływem na opinię publiczną. Wreszcie po trzecie, skarżący zwrócili uwagę na surowość sankcji nałożonych przez sądy krajowe, argumentując, że były one całkowicie nieproporcjonalne.

W odpowiedzi na skargę rząd Azerbejdżanu przyznał, że skazanie skarżących stanowiło ingerencję $\mathrm{w}$ ich prawo do wolności wypowiedzi, jednak ingerencja ta była uzasadniona treścią art. 283 kodeksu karnego i służyła realizacji uzasadnionych celów wskazanych w Konwencji:

45 Por. tamże, § 44: „The issue before the Court therefore involves weighing up the conflicting interests of the exercise of two fundamental freedoms, namely the right of the applicants to impart to the public their views on religion in the press on the one hand, and the right of others to respect for their freedom of thought, conscience and religion on the other".

46 Por. tamże, § 28. 
„ochrony praw innych osób” i „zapobiegania zakłócaniu porządku” 47 . Rząd podnosił również, że skazanie skarżących było podyktowane pilną potrzebą społeczną, ponieważ kwestionowany artykuł stanowił obelżywy atak na religię, w szczególności islam, oraz obraził uczucia religijne, katalizując silną reakcję publiczną na ten artykuł (zostały wydane publiczne oświadczenia potępiające ten artykuł, a na przedmieściach Baku miały miejsce wiece) ${ }^{48}$. Odwołując się do orzecznictwa ETPC, rząd Azerbejdżanu, usprawiedliwiając swoją ingerencję, oświadczył, że władze krajowe $\mathrm{w}$ sprawach dotyczących moralności mają pozostawiony margines uznania $^{49}$ przy ocenie istnienia konieczności i zakresu ingerencji $\mathrm{w}$ wolność wypowiedzi, gdyż w Europie nie jest możliwe ustalenie jednolitego standardu określającego miejsce i rolę religii w życiu publicznym. Sądy krajowe zatem - zdaniem rządu - orzekły tak, a nie inaczej, bo było to uzasadnione w ich opinii i osiągnęły właściwą równowagę między prawami chronionymi na mocy art. 9 i 10 Konwencji.

Orzekając w tej sprawie, Trybunał był zobowiązany sprawdzić, czy ingerencja $\mathrm{w}$ wolność wypowiedzi skarżących, co samo $\mathrm{w}$ sobie nie było przedmiotem sporu, była uzasadniona i w następstwie tego zgodna z konwencją. Za taką może być uznana wyłącznie ingerencja, która jest „przewidziana przez prawo", realizuje jeden lub więcej uzasadnionych celów wskazanych w ust. 2 art. 10 EKPC i jest „konieczna w społeczeństwie demokratycznym" ${ }^{50}$ do osiągnięcia takiego celu.

47 Por. tamże, § 29.

48 Tamże, § 30.

49 Pełnomocnik rządu Azerbejdżanu, powołując się na tzw. margines ocen, próbował przekonać Trybunał, że sądy krajowe miały w tym zakresie prawo dokonać wykładni przepisów prawa w kontekście realiów kraju, w którym orzekają. Była to próba odwołania się do formuły stosowanej przez ETPC w sytuacjach, gdy Trybunał zostawia znaczną przestrzeń uprawnień ocennych w danej sprawie państwu, kontrolując, czy ocena taka nie narusza istoty Konwencji. O marginesie ocen przede wszystkim: A. Wiśniewski, Koncepcja marginesu oceny w orzecznictwie Europejskiego Trybunału Praw Człowieka, Gdańsk 2008, s. 482; ponadto m.in.: I.C. Kamiński, Ograniczenia swobody wypowiedzi..., s. 63-67; J. Kapelańska-Pręgowska, Koncepcja tzw. marginesu oceny w orzecznictwie ETPC, Państwo i Prawo 2007, z. 12, s. 87-99; A. Wiśniewski, The European Court of Human Rights. Between Judicial Activism and Passivism, Gdańsk 2016, s. 105-156.

${ }^{50} \mathrm{Na}$ temat kryterium „konieczności w społeczeństwie demokratycznym” zob. L. Leszczyński, Kryterium konieczności w demokratycznym społeczeństwie w Europejskiej Konwencji Praw Człowieka - studium teoretycznoprawne, Europejski Przegląd Sądowy 2014, nr 1, s. $48-52$. 
Analizując dwa pierwsze kryteria, ETPC uznał, przychylając się do stanowiska rządu Azerbejdżanu i nie wdając się w szczegółowe rozważania i uzasadnienia, że ingerencja była przewidziana przez prawo i realizowała dwa z uzasadnionych i wskazanych w Konwencji celów: „ochronę praw innych” i „konieczność zapobieżenia zakłóceniu porządku”. Takie stanowisko Trybunału budzi poważne wątpliwości w świetle analizy brzmienia art. 283 azerbejdżańskiego kodeksu karnego, w świetle treści artykułu autorstwa Tagiyeva, w świetle błędów azerbejdżańskiego wymiaru sprawiedliwości $\mathrm{w}$ tej sprawie, a także w świetle argumentacji podnoszonej we wcześniejszych orzeczeniach ETPC w podobnych sprawach oraz w uzasadnieniu w tej sprawie, o czym w dalszej części artykułu.

Skoro jednak Trybunał przyjął, że ingerencja była przewidziana przez prawo i realizowała dwa z uzasadnionych i wskazanych w Konwencji celów, decydujące znaczenie $\mathrm{w}$ analizowanej sprawie miała mieć kwestia, czy ingerencja była konieczna w społeczeństwie demokratycznym. Temu zagadnieniu ETPC poświęcił w swoim uzasadnieniu zasadniczą część rozważań, przypominając najważniejsze dotychczasowe reguły swego orzekania w tym zakresie.

Trybunał podkreślił, że ogólne zasady oceny czy ingerencja w korzystanie z prawa do wolności wypowiedzi była „niezbędna w społeczeństwie demokratycznym", są dobrze ugruntowane w jego orzecznictwie, były także wielokrotnie powtarzane $\mathrm{w}$ jego orzeczeniach ${ }^{51}$. Trybunał po raz kolejny przypomniał, że wolność słowa stanowi jeden z podstawowych fundamentów społeczeństwa demokratycznego i jeden z podstawowych warunków jego rozwoju i samorealizacji każdej osoby, dodając, że z zastrzeżeniem art. 10 ust. 2 ETPC ma on zastosowanie nie tylko do przekazów lub idei, które są przyjmowane przychylnie lub uważane za nieobraźliwe bądź obojętne, ale także do tych, które obrażają, szokują lub przeszkadzają. Takie, zdaniem Trybunału, są wymagania pluralizmu, tolerancji i otwartości, bez nich zaś nie ma „społeczeństwa demokratycznego". Trybunał przypomniał, że tzw. margines uznania dla państw w przypadku debaty dotyczącej tematów będących przedmiotem zainteresowania publicznego jest minimalny, choć oczywiście na korzystających z wolności wypowiedzi ciążą obowiązki i odpowiedzialność, m.in. te,

51 Por. wyrok ETPC z dnia 5 grudnia 2019 r. w sprawie Tagiyev i Huseynov v. Azerbejdżan, $§ 36$. 
które wynikają z praw innych osób, wśród nich chronionych art. 9 EKPC ${ }^{52}$. Trybunał podkreślił, że w kontekście przekonań religijnych przyjmuje się ogólny wymóg zapewnienia posiadaczom takich przekonań pokojowego korzystania z praw gwarantowanych na mocy art. 9, co rodzi oczywisty obowiązek unikania, w możliwie najwyższym stopniu, wypowiedzi dotyczących przedmiotów czci, będących w nieuzasadniony sposób obraźliwymi lub bluźnierczymi. Kiedy wypowiedzi wykraczają poza dopuszczalne granice dezaprobaty czy negacji przekonań religijnych innych osób i stanowią nawoływanie do nietolerancji religijnej, $\mathrm{np}$. w przypadku niewłaściwego lub obelżywego ataku na przedmiot kultu religijnego, państwo może zasadnie uznać je za niezgodne z poszanowaniem wolności myśli, sumienia i wyznania oraz podjąć proporcjonalne środki ograniczające. Trybunał dodał w tym kontekście, że w szczególności w odniesieniu do ingerencji $\mathrm{w}$ wolność wypowiedzi w sprawach dotyczących wypowiedzi, które rzekomo wywołują lub uzasadniają przemoc, nienawiść lub nietolerancję, Trybunał zawsze przypominał, iż tolerancja i poszanowanie równej godności wszystkich ludzi stanowią podstawy demokratycznego, pluralistycznego społeczeństwa. Dlatego w społeczeństwach demokratycznych można z zasady uznać wręcz za konieczne zapobieganie wszelkim formom wypowiedzi, które szerzą, podżegają, promują lub usprawiedliwiają przemoc czy nienawiść z powodu nietolerancji, pod warunkiem, że zastosowane ograniczenia są proporcjonalne ${ }^{53}$ do zgodnego z prawem zamierzonego celu.

Trybunał przypomniał i przyznał również, że badając, czy ograniczenia praw i wolności gwarantowanych przez Konwencję można uznać za „konieczne w społeczeństwie demokratycznym", często stwierdzał, że brak jednolitego europejskiego standardu dotyczącego ochrony praw innych osób w związku z atakami na ich przekonania religijne poszerza margines uznania państw przy regulowaniu wolności wypowiedzi w sprawach mogących naruszać osobiste przekonania w zakresie moralności lub religii. Jednak przymiotnik „konieczny” implikuje istnienie „naglącej potrzeby społecznej", którą należy w sposób przekonujący ustalić ${ }^{54}$. Sędziowie pod-

52 Por. tamże, § 37.

53 Na temat proporcjonalności szczegółowo: A. Wiśniewski, Proporcjonalność i fair balance w orzecznictwie Europejskiego Trybunału Praw Człowieka, Gdańskie Studia Prawnicze 2019, nr 2, s. 57-70.

54 Por. wyrok ETPC z dnia 5 grudnia 2019 r. w sprawie Tagiyev i Huseynov v. Azerbejdżan, $§ 40$. 
kreślili, że to do organów krajowych należy przede wszystkim ocena, czy istnieje taka potrzeba, która może uzasadnić ingerencję, i w tym celu korzystają one z pewnego marginesu uznania, ale w kontekście wolności prasy władzom krajowym przysługuje bardzo ograniczony margines uznania przy ocenie, czy istnieje "nagląca potrzeba społeczna”. Wreszcie, co nie może ujść uwadze, przedmiotowy margines oceny państwa podlega nadzorowi Trybunału. Nadzór dotyczy zarówno litery prawa, jak i jego zastosowania nawet przez niezależne sądy. Trybunał jest zatem uprawniony do wydania ostatecznego rozstrzygnięcia, czy „ograniczenie” można pogodzić z wolnością wypowiedzi chronioną na mocy art. 10 EKPC. Rozwijając rozważania dotyczące nadzoru, Trybunał podkreślił, że jego funkcja nadzorcza nie ogranicza się wyłącznie do ustalenia, czy władze krajowe korzystały ze swobody uznania w sposób rozsądny, ostrożny i w dobrej wierze. Ma on obowiązek zbadać ingerencję w świetle całej sprawy i ustalić, czy powody przedstawione przez władze krajowe w celu jej uzasadnienia były odpowiednie i wystarczające oraz czy podjęty środek był proporcjonalny do zgodnego z prawem zamierzonego celu. Czyniąc to, Trybunał upewnia się, że władze krajowe, opierając się na poprawnej ocenie istotnych faktów, zastosowały standardy, które były zgodne z zasadami zawartymi w art. 10 Konwencji. W celu ustalenia proporcjonalności ingerencji Trybunał rozważa zakwestionowaną ingerencję nie tylko w świetle spornych treści, ale także w kontekście, w jakim zostały one umieszczone. Czynnikami, które przy ocenie konieczności ingerencji należy wziąć pod uwagę, są również charakter i dotkliwość nałożonej kary. W ten sposób Trybunał zarysował ramy, w których zamierzał rozstrzygać skargę w sprawie Tagiyev i Huseynov v. Azerbejdżan ${ }^{55}$. W tym miejscu nie można jednak nie zauważyć,

55 ETPC, orzekając w sprawie Tagiyev i Huseynov v. Azerbejdżan, odwoływał się do zasad formułowanych we wcześniejszych orzeczeniach, m.in.: wyroku ETPC z dnia 29 czerwca 2004 r. w sprawie Chauvy and Others v. Francja; wyroku ETPC z dnia 13 września 2005 r. w sprawie İ.A. v. Turcja; wyroku ETPC z dnia 31 stycznia 2006 r. w sprawie Giniewski v. Francja; wyroku ETPC z dnia 2 maja 2006 r. w sprawie Aydın Tatlav v. Turcja; wyroku ETPC z dnia 22 kwietnia 2010 r. w sprawie Fatullayev v. Azerbejdżan; wyroku ETPC z dnia 15 października 2015 r. w sprawie Perinçek v. Szwajcaria; wyroku ETPC z dnia 20 października 2015 r. w sprawie Pentikäinen v. Finlandia; wyroku ETPC z dnia 19 stycznia 2016 r. w sprawie Görmüş and Others v. Turcja; wyroku ETPC z dnia 29 marca 2016 r. w sprawie Bédat v. Szwajcaria; wyroku ETPC z dnia 23 czerwca 2016 r. w sprawie Baka v. Węgry; wyroku ETPC z dnia 27 czerwca 2017 r. w sprawie Satakunnan Markkinapörssi Oy and Satamedia Oy v. Finlandia; wyroku ETPC z dnia 3 października 2017 r. w sprawie Dmitriyevskiy v. Rosja; wyroku ETPC z dnia 30 stycznia 2018 r. w sprawie Sekmadienis 
że wszystkie przywołane przez Trybunał reguły orzekania dotyczące „konieczności ingerencji" prowadzą do uzasadnionego wniosku, że sędziowie zbyt pochopnie, a nawet bezpodstawnie uznali, iż ingerencja władz państwowych Azerbejdżanu była przewidziana przez prawo i realizowała dwa uzasadnione cele wskazane w Konwencji.

Orzekając, Trybunał wyszedł od uwagi, że rząd Azerbejdżanu na żadnym etapie sprawy nie podniósł zarzutu, iż kwestionowane opinie zawarte $\mathrm{w}$ artykule autorstwa Tagiyeva stanowiły mowę nienawiści i że $\mathrm{z}$ tego właśnie powodu skarżący nie powinni korzystać z ochrony w ramach wolności wypowiedzi, gdyż jej nadużyli, realizując dyspozycję art. 17 EKPC. Zatem ETPC wprost wskazuje, że ingerencję władz Azerbejdżanu w wolność wypowiedzi Tagiyeva i Husynova mógłby uzasadnić zarzut, iż publikacja stanowiła mowę nienawiści ${ }^{56}$. Wydaje się, że jest to kluczowa perspektywa przyjęta przez Trybunał podczas konstruowania orzeczenia w tej sprawie. Kontynuując tę myśl, Trybunał jednocześnie podkreślił, że sam nie znalazł $w$ aktach sprawy niczego, co sugerowałoby, że podnoszenie takiego zarzutu byłoby uzasadnione. Nie można w tym miejscu wobec tego nie postawić pytania, dlaczego zatem ETPC przyjął w sprawie, że ingerencja państwa była przewidziana przez prawo, skoro w tym samym uzasadnieniu stwierdził, że nie znalazł w aktach sprawy niczego, co sugerowałoby, że podnoszenie zarzutu mowy nienawiści w artykule autorstwa Tagiyeva byłoby uzasadnione, a właśnie nawoływanie do nienawiści lub wrogości jest przedmiotem dyspozycji art. 283 azerbejdżańskiego kodeksu karnego.

Trybunał wskazując sedno swego orzekania w przedmiotowej sprawie w wyważeniu sprzecznych interesów dotyczących korzystania z dwóch wolności: prawa skarżących do przekazywania opinii publicznej swoich poglądów na temat religii w prasie oraz prawa innych do poszanowania ich wolności myśli, sumienia i wyznania, przypomniał również, że grupa religijna musi tolerować zaprzeczanie przez innych ich przekonań

Ltd. v. Litwa; wyroku ETPC z dnia 13 marca 2018 r. w sprawie Stern Taulats and Roura Capellera v. Hiszpania; wyroku ETPC z dnia 28 czerwca 2018 r. w sprawie Paraskevopoulos v. Grecja; wyroku ETPC z dnia 17 lipca 2018 r. w sprawie Maria Alekhina and Others v. Rosja; wyroku ETPC z dnia 25 września 2018 r. w sprawie E.S. v. Austria. Wszystkie wyroki są dostępne w bazie HUDOC: https://hudoc.echr.coe.int/eng\#\{\%22documentco llectionid2\%22:[\%22GRANDCHAMBER\%22,\%22CHAMBER\%22]\} [dostęp: 3.01 .2020 r.].

56 O mowie nienawiści szerzej: L.K. Jaskuła, Wolność działalności dziennikarskiej w perspektywie zjawiska mowy nienawiści (wybrane aspekty prawne), w: Status prawny..., s. 315-343. 
religijnych, a nawet propagowanie przez innych doktryn wrogich ich wierze, o ile sporne wypowiedzi nie nawołują do nienawiści lub nietolerancji religijnej. Trybunał uznał, że choć niektóre z zawartych w artykule sformułowań odnosiły się do religii islamu i mogły być odczytane przez część religijnych, wyznających islam osób jako obraźliwy atak na proroka Mahometa i muzułmanów żyjących w Europie, a nawet jako wypowiedzi potencjalnie mogące wywoływać nienawiść religijną, to z lektury całego tekstu artykułu jasno wynika, że dotyczył on głównie porównania wartości zachodnich i wschodnich oraz wyrażał poglądy autora tekstu na temat roli religii w kształtowaniu się tych wartości, a także ich wpływu na kontekst praw człowieka i ich rozwoju na świecie i w Azerbejdżanie. Z tego powodu artykuł nie powinien być analizowany tylko w kontekście kwestii związanych z religią, ale także $w$ kontekście debaty dotyczącej tematów, które stanowią przedmiot zainteresowania publicznego, a mianowicie roli religii w społeczeństwie oraz jej roli w rozwoju społeczeństwa. I to przede wszystkim do sądów krajowych należało przeprowadzenie kompleksowej oceny kwestionowanych uwag w taki sposób - przedstawienie odpowiednich i wystarczających powodów uzasadnienia ingerencji oraz staranne wyważenie prawa skarżących do wolności wypowiedzi i ochrony prawa osób religijnych do bycia nieobrażanym z powodu ich wiary, czego sądy krajowe nie zrobiły ${ }^{57}$. Co gorsza, w ocenie Trybunału sądy krajowe ograniczyły się do powtórzenia wniosków z raportu sporządzonego w ramach postępowania śledczego, nie wyjaśniając, dlaczego poszczególne uwagi zawarte $\mathrm{w}$ artykule zostały uznane za podżeganie do nienawiści religijnej i wrogości, nie analizując sprawozdania, a jedynie przyjmując i uznając jego wnioski. Taką sytuację Trybunał uznał za niedopuszczalną, ponieważ wszystkie kwestie prawne muszą być rozstrzygane wyłącznie przez sąd. W tej zaś sprawie doszło do sytuacji, w której to nie sąd rozstrzygał w kluczowych kwestiach prawnych, a urzędnik administracyjny. Zatem ponownie należy postawić pytanie, dlaczego więc Trybunał uznał, że ingerencja była przewidziana przez prawo, skoro na żadnym etapie postępowania krajowego nie zostało to wykazane i dlaczego ingerencja stanowiła "ochronę praw innych", skoro z akt sprawy i argumentacji Trybunału wynika, że do naruszania praw innych osób nie doszło.

57 Por. wyrok ETPC z dnia 5 grudnia 2019 r. w sprawie Tagiyev i Huseynov v. Azerbejdżan, § 45 i 46 . 
Sądy krajowe nie przeprowadziły również żadnej oceny kwestionowanych wypowiedzi przez zbadanie ich w ogólnym kontekście artykułu. Zabrakło oceny intencji autora oraz oceny wagi poruszanego w tekście artykułu tematu w kontekście interesu publicznego, a to właśnie sądy krajowe $\mathrm{w}$ takich postępowaniach są zobowiązane do zbadania, czy kontekst sprawy, interes publiczny i intencja autora kwestionowanego artykułu uzasadniają ewentualne zastosowanie pewnego stopnia prowokacji lub przesady. Sądy krajowe - w opinii Trybunału - w swoich orzeczeniach nawet nie próbowały dokonać ważenia prawa skarżących do wolności wyrażania opinii z ochroną prawa osób religijnych do tego, by nie obrażano ich ze względu na ich wierzenia ${ }^{58}$. Przyjmując tę argumentację Trybunału za uzasadnioną i słuszną, nieuzasadnione jest uznanie przez Trybunał, że ingerencja państwa była przewidziana przez prawo i stanowiła ochronę wskazanych w Konwencji celów - argumentacja Trybunału wręcz prowadzi wprost do wniosku przeciwnego: że $\mathrm{w}$ tej sprawie, $\mathrm{w}$ świetle poczynionych przez Trybunał ustaleń, nie można mówić o ingerencji przewidzianej przez prawo i ochronie realizacji wskazanych w Konwencji celów, skoro nie zostały podjęte i przeprowadzone podstawowe czynności, nie dowiedziono złamania prawa, a sądy krajowe nie miały podstaw, by obiektywnie rozstrzygnąć, czy do złamania prawa przez skarżących doszło, czy nie doszło.

Trybunał podkreślił również, że konieczne jest zwrócenie uwagi na surowość kar nałożonych na skarżących, którzy zostali skazani w postępowaniu karnym odpowiednio na trzy i cztery lata pozbawienia wolności, spędzając jedenaście miesięcy w więzieniu. Zwrócił uwagę, że biorąc pod uwagę istnienie $\mathrm{w}$ postępowaniu karnym możliwości zastosowania innych środków, skazanie na karę pozbawienia wolności stanowi poważną sankcję. Chociaż orzekanie w tym zakresie pozostaje zasadniczo w gestii sądów krajowych, Trybunał nie uznał, aby okoliczności przedmiotowej sprawy stanowiły jakiekolwiek uzasadnienie nałożenia na skarżących tak surowych sankcji, które dodatkowo mogły wywołać efekt zniechęcający (a chilling effect) do korzystania $\mathrm{z}$ wolności słowa $\mathrm{w}$ Azerbejdżanie oraz odwodzić prasę od otwartego omawiania kwestii związanych z religią, jej rolą $\mathrm{w}$ społeczeństwie lub omawiania innych tematów będących przedmiotem zainteresowania opinii publicznej ${ }^{59}$.

\footnotetext{
58 Por. tamże, § 48.

59 Tamże, § 49 .
} 
Trybunał skonstatował, że w niniejszej sprawie nie może uznać uzasadnienia przedstawionego przez sądy krajowe za istotne i wystarczające dla uzasadnienia przedmiotowej ingerencji ${ }^{60}$, przyjmując jednocześnie, iż ustalenia poczynione $\mathrm{w}$ trakcie postępowania strasburskiego są wystarczające, aby stwierdzić, że skazanie skarżących za przestępstwo było nieproporcjonalne $\mathrm{w}$ stosunku do zamierzonych celów, a tym samym skazanie nie było „konieczne w społeczeństwie demokratycznym” i stanowi naruszenie art. 10 EKPC.

\section{Zakończenie}

Sprawa Tagiyev i Huseynov v. Azerbejdżan po raz kolejny uświadamia fakt, że kolizyjność wolności wypowiedzi i wolności wyznania nie jest zagadnieniem czysto teoretycznym, a jej skutki mogą być tragiczne. Powinniśmy również mieć świadomość, że zagadnienie jest aktualne i bynajmniej nie dotyczy wyłącznie Azerbejdżanu.

Analiza normatywnych modeli obu wolności zawartych w EKPC i sprawy Tagiyev i Huseynov v. Azerbejdżan prowadzi do wniosku, że Trybunał, orzekając w tej sprawie, choć uznał, iż ingerencja władz krajowych w wolność wypowiedzi była przewidziana przez prawo i służyła ochronie celów wskazanych w Konwencji, to jednocześnie wykazał cały szereg zaniedbań podczas postępowania prowadzonego przez sądy krajowe w Azerbejdżanie, które doprowadziły Trybunał do konkluzji, że ingerencja nie była konieczna w społeczeństwie demokratycznym, a tym samym, że Konwencję naruszono. Autorka podziela konkluzję Trybunału o naruszeniu Konwencji, jednak uważa, że podstawą naruszenia nie było wyłącznie niewykazanie „,konieczności ingerencji w społeczeństwie demokratycznym”, ale również niewykazanie, że ingerencja była „przewidziana przez prawo" oraz że służyła "ochronie wskazanych w Konwencji celów”.

Orzeczenie nie stanowi przełomu w orzekaniu i jest zasadniczo jego kontynuacją, ponieważ w podstawowych kwestiach dotyczących kolizji wolności wypowiedzi i wolności wyznania nie zmienia linii orzeczniczej ETPC, jednak w przedmiocie orzekania jest kolejnym ważnym i zasługującym na analizę wyrokiem - wykracza poza aplikację dotychczasowego 
orzecznictwa, dotyczy głośniej sprawy, której stan faktyczny stał się podstawą orzekania oraz nie był dotąd przedmiotem analizy doktryny.

Możemy z niego wypreparować konkretne zalecenia generalne Trybunału, o których sądy krajowe orzekające w podobnych sprawach powinny pamiętać. Należy również zauważyć, że sędziowie Trybunału także w tej sprawie po raz kolejny potwierdzili następującą formułę - w sprawach dotyczących religii i moralności państwom-stronom Konwencji przysługuje znaczny margines uznania przy ocenie istnienia konieczności i zakresu ingerencji w wolność wypowiedzi, gdyż w Europie nie jest możliwe ustalenie jednolitego standardu określającego miejsce i rolę religii w życiu publicznym. Przyjęli jednocześnie, że margines uznania krajowego jest znacznie zawężony w przypadku, gdy sprawy dotyczące religii i moralności są elementem debaty publicznej na tematy będące przedmiotem zainteresowania publicznego i są rozpatrywane na gruncie art. 10 EKPC. W taki sposób sędziowie uzasadnili ograniczenie zakresu marginesu, tak też w przedmiotowej sprawie orzekał Trybunał - stwierdzenie, że doszło do naruszenia Konwencji w sprawie Tagiyev i Huseynov v. Azerbejdżan było możliwe dzięki temu, że kwestionowany artykuł został uznany za głos w debacie będącej przedmiotem zainteresowania publicznego. Dokonując takiej kwalifikacji wypowiedzi Tagiyeva, przy stwierdzeniu, że nie wypełniała ona znamion mowy nienawiści, Trybunał mógł uznać, że ingerencja w wolność wypowiedzi dziennikarza była nieproporcjonalna, a zastosowany środek zbyt surowy w społeczeństwie demokratycznym. Kwestia stosowania formuły marginesu oceny w orzecznictwie ETPC jest przedmiotem dyskusji w doktrynie ${ }^{61}$. Zdaniem zwolenników ograniczenia jej stosowania używanie tej formuły może rodzić sytuację niepewności ochrony konwencyjnej i nieprzewidywalności orzeczeń Trybunału ${ }^{62}$. W sytuacji ciągle rosnącej

${ }^{61}$ Zagadnienie to w sposób najbardziej szczegółowy prezentuje w polskiej literaturze A. Wiśniewski. Analizując przedmiotową dyskusję, stwierdza, że „W debacie nad koncepcją marginesu oceny można wyróżnić generalnie trzy stanowiska dotyczące doktryny marginesu oceny w orzecznictwie strasburskim. Pierwsze, które można by nazwać radykalnym, zajmują ci autorzy, którzy krytykując doktrynę marginesu oceny, postulują jej odrzucenie przez Trybunał. Drugie stanowisko, bardziej umiarkowane, nie neguje samej doktryny, ale wychodzi z krytyką sposobu jej stosowania przez ETPC. Trzecie natomiast broni koncepcji marginesu oceny, traktując ją, jako uzasadnioną w orzecznictwie Trybunału”, A. Wiśniewski, Koncepcja marginesu oceny..., s. 413.

62 Por. I.C. Kamiński, Fatalny margines ocen, Kultura Liberalna 2011, nr 132, https:/ / kulturaliberalna.pl/2011/07/21/bodnar-sadurski-wieruszewski-kowalski-kaminski-czy- 
liczby skarg indywidualnych obywateli państw-stron nienależących do kręgu kultury europejskiej Trybunał coraz częściej będzie konfrontowany z koniecznością ponownego przemyślenia zasadności dalszego stosowania tej formuły, ponieważ powołując się na nią, część państw-stron Konwencji próbuje sankcjonować zupełnie różne od wyznaczonych przez „europejskie parametry" rozumienie praw człowieka. Prawa człowieka zaś, mające jako swoje źródło godność osobową, nie są kategorią, która powinna podlegać relatywizowaniu $\mathrm{w}$ zależności od definiowania np. moralności czy miejsca religii $w$ społeczeństwie. Odpowiedzi na te wątpliwości należy wypatrywać w kolejnych orzeczeniach ETPC, a moment, w którym Trybunał zdecyduje się zrezygnować w orzekaniu z używania tej formuły lub wyraźne ją ograniczy, będzie zdecydowanym przełomem w historii orzecznictwa ETPC.

-krzyz-to-szkolny-mebel/ [dostęp: 3.01.2020 r.]. Autor stoi na stanowisku, że odwoływanie się przez ETPC w orzeczeniach do pojęcia marginesu swobody ocen było uzasadnione, gdy orzecznictwo strasburskie się kształtowało: „Na koniec kilka uwag o problemie krajowego marginesu swobody ocen. Jest to pojęcie w orzecznictwie strasburskim tyleż kluczowe, co fatalne. Jego użycie było uprawnione, gdy strasburskie orzecznictwo dopiero się kształtowało i powstawało naturalne pytanie o to, ile uprawnień ocennych ma państwo, a ile Trybunał. Dzisiaj jest to natomiast rodzaj zasłony dymnej - konstrukcja, która ma nam raczej pewne rzeczy wmówić, podczas gdy w rzeczywistości Trybunał orzeka w zupełnie inny sposób, odwołując się do całkiem precyzyjnie ujmowanych «europejskich parametrów»". Dla poparcia swojego punktu widzenia Kamiński przytacza opinię belgijskiego sędziego Jana De Meyera: „Najlepiej chyba podsumowuje tę krytykę następująca opinia sędziowska z roku 1997: nadszedł najwyższy czas, by Trybunał pozbył się w swojej argumentacji tego pojęcia. Zbyt długo zwlekano z porzuceniem tej wyświechtanej frazy i z wyrzeczeniem się relatywizmu, jaki ona rodziła. Tam, gdzie chodzi o prawa człowieka, nie ma miejsca na margines ocen, który zezwala państwu na podjęcie decyzji o tym, co jest akceptowane. Puste słowa dotyczące marginesu ocen rodzą ograniczenia, które nie są konieczne, powodując w sposób trudny do zaakceptowania, że państwo może zrobić wszystko, czego Trybunał nie uzna za sprzeczne z prawami człowieka. Taka terminologia błędna co do zasady i chybiona w praktyce powinna zostać natychmiast porzucona. Nie jest to bynajmniej cytat z lewicującego akademika [kontynuuje I.C. Kamiński] ani z jakiegoś szalonego euroentuzjasty, a pogląd wyrażony przez niezwykle konserwatywnego sędziego belgijskiego Jana De Meyera, który zasiadał w Trybunale w Strasburgu. Warto o tym stwierdzeniu pamiętać". 


\section{Bibliografia}

\section{Źródła}

\section{Akty prawne}

Konwencja o Ochronie Praw Człowieka i Podstawowych Wolności, Dz. U. z 1993 r. Nr 61, poz. 284 z późn. zm.

\section{Orzecznictwo}

Wyrok ETPC z dnia 7 grudnia 1976 r. w sprawie Handyside v. Wielka Brytania [baza danych HUDOC].

Wyrok ETPC z dnia 25 maja 1993 r. w sprawie Kokkinakis v. Grecja [baza danych HUDOC].

Wyrok ETPC z dnia 20 września 1994 r. w sprawie Otto-Preminger-Institut v. Austria [baza danych HUDOC].

Wyrok ETPC z dnia 29 czerwca 2004 r. w sprawie Chauvy and Others v. Francja [baza danych HUDOC].

Wyrok ETPC z dnia 13 września 2005 r. w sprawie İ.A. v. Turcja [baza danych HUDOC].

Wyrok ETPC z dnia 31 stycznia 2006 r. w sprawie Giniewski v. Francja [baza danych HUDOC].

Wyrok ETPC z dnia 2 maja 2006 r. w sprawie Aydın Tatlav v. Turcja [baza danych HUDOC].

Wyrok ETPC z dnia 22 kwietnia 2010 r. w sprawie Fatullayev v. Azerbejdżan [baza danych HUDOC].

Wyrok ETPC z dnia 15 października 2015 r. w sprawie Perinçek v. Szwajcaria [baza danych HUDOC].

Wyrok ETPC z dnia 20 października 2015 r. w sprawie Pentikäinen v. Finlandia [baza danych HUDOC].

Wyrok ETPC z dnia 19 stycznia 2016 r. w sprawie Görmüş and Others v. Turcja. [baza danych HUDOC].

Wyrok ETPC z dnia 29 marca 2016 r. w sprawie Bédat v. Szwajcaria [baza danych HUDOC] [baza danych HUDOC].

Wyrok ETPC z dnia 23 czerwca 2016 r. w sprawie Baka v. Węgry [baza danych HUDOC].

Wyrok ETPC z dnia 27 czerwca 2017 r. w sprawie Satakunnan Markkinapörssi Oy and Satamedia Oy v. Finlandia [baza danych HUDOC].

Wyrok ETPC z dnia 3 października 2017 r. w sprawie Dmitriyevskiy v. Rosja [baza danych HUDOC].

Wyrok ETPC z dnia 30 stycznia 2018 r. w sprawie Sekmadienis Ltd. v. Litwa [baza danych HUDOC]. 
Wyrok ETPC z dnia 13 marca 2018 r. w sprawie Stern Taulats and Roura Capellera v. Hiszpania [baza danych HUDOC].

Wyrok ETPC z dnia 28 czerwca 2018 r. w sprawie Paraskevopoulos v. Grecja [baza danych HUDOC].

Wyrok ETPC z dnia 17 lipca 2018 r. w sprawie Maria Alekhina and Others v. Rosja [baza danych HUDOC].

Wyrok ETPC z dnia 25 września 2018 r. w sprawie E.S. v. Austria [baza danych HUDOC].

Wyrok ETPC z dnia 5 grudnia 2019 r. w sprawie Tagiyev i Huseynov v. Azerbejdżan [baza danych HUDOC].

\section{Literatura}

Falski J., Symbolika i przekonania religijne w miejscu pracy (na tle wyroku Europejskiego Trybunatu Praw Człowieka w sprawie Eweida i inni v. Wielka Brytania), Państwo i Prawo 2015, z. 8.

Helsińska Fundacja Praw Człowieka, Wolność mediów w Azerbejdżanie - apel do Komitetu Ministrów Rady Europy, 25.01.2018 r., http:/ / www.hfhr.pl/wolnosc-mediow-w-azerbejdzanie-apel-do-komitetu-ministrow-rady-europy / [dostęp: 31.12.2019 r.].

Jagielski W., Niedemokratyczny Azerbejdzan przewodzi Radzie Europy, Depesza PAP z 1.06.2014 r., https://www.prawo.pl/prawnicy-sady/niedemokratyczny-azerbejdzan-przewodzi-radzie-europy,56297.html [dostęp: 31.12.2019 r.].

Jan Paweł II, List apostolski z 1.09.1980 r. o wolności religijnej (L'eglise Catholique), http:/ / www.apostol.pl/janpawelii/listy-apostolskie/o-wolno\% C5\%9Bci-religijnej-leglise-catholique [dostęp: 30.12.2019 r.].

Jaskuła L.K., Prawo do dobrego imienia a wolność prasy, Warszawa 2008.

Jaskuła L.K., Uczucia religijne jako granica wolności wypowiedzi (wybrane zagadnienia prawne), w: Praktyczne aspekty wolności wypowiedzi, red. W. Lis, Z. Husak, Toruń 2011.

Jaskuła L.K., Wolność działalności dziennikarskiej w perspektywie zjawiska mowy nienawiści (wybrane aspekty prawne), w: Status prawny dziennikarza, red. W. Lis, Warszawa 2014.

Kamiński I.C., Fatalny margines ocen, Kultura Liberalna 2011, nr 132.

Kamiński I.C., Media w europejskiej konwencji o ochronie praw człowieka i podstawowych wolności, w: Prawo mediów, red. J. Barta, R. Markiewicz, A. Matlak, Warszawa 2008.

Kamiński I.C., Ograniczenia swobody wypowiedzi dopuszczalne w Europejskiej Konwencji Praw Człowieka. Analiza krytyczna, Warszawa 2010.

Kamiński I.C., Uprawnienia i obowiązki dziennikarskie w orzecznictwie Europejskiego Trybunału Praw Człowieka, w: Status prawny dziennikarza, red. W. Lis, Warszawa 2014. 
Kamiński I.C., Wolność religijna a jednostka, w: Prawne granice sumienia i wyznania, red. J. Kondratiewa-Bryzik, R. Wieruszewski, M. Wyrzykowski, 2012 [wyd. el. LEX].

Kapelańska-Pręgowska J., Koncepcja tzw. marginesu oceny w orzecznictwie ETPC, Państwo i Prawo 2007, z. 12.

Konwencja o Ochronie Praw Człowieka i Podstawowych Wolności, t. 1. Komentarz do artykułów 1-18, red. L. Garlicki, Warszawa 2010 [baza danych Legalis].

Leszczyński L., Kryterium konieczności w demokratycznym społeczeństwie w Europejskiej Konwencji Praw Człowieka - studium teoretycznoprawne, Europejski Przegląd Sądowy 2014, nr 1.

Pełnomocnik Ministra Spraw Zagranicznych ds. postępowań przed Europejskim Trybunałem Praw Człowieka, Raport z wykonania wyroków Europejskiego Trybunału Praw Człowieka przez Polskę za 2018 rok, Warszawa 2019, https:/ / www.sw.gov.pl/assets/66/58/71/9daae6481ba6c151aece0468936a7 bd587ae36c8.pdf [dostęp: 31.12.2019 r.].

Reporters Without Borders, Worldwide round-up of journalists killed, detained, held hostage, or missing in 2019, https://rsf.org/en/news/rsf-yearly-round-historically-low-number-journalists-killed-2019 [dostęp: 26.12.2019 r.].

Rezolucja Parlamentu Europejskiego z dnia 15 grudnia 2011 r. w sprawie Azerbejdżanu, zwłaszcza przypadku Rafiga Tagiego (2013/C 168 E/15), Dz. Urz. UE C z 14.06.2013.

Skrzydło J., Wolność słowa w orzecznictwie Sądu Najwyższego Stanów Zjednoczonych i Europejskiego Trybunału Praw Człowieka. Analiza porównawcza, Toruń 2013.

Sobczak J., Swoboda wypowiedzi w orzecznictwie Trybunału Praw Człowieka w Strasburgu. Część I, Ius Novum 2007, nr 2-3.

Sobczak J., Swoboda wypowiedzi w orzecznictwie Trybunału Praw Człowieka w Strasburgu. Część II, Ius Novum 2007, nr 4.

Sobczak J., Zawód dziennikarza w optyce Europejskiego Trybunatu Praw Człowieka. Między idealistycznym a realistycznym paradygmatem wolności prasy, w: Status prawny dziennikarza, red. W. Lis, Warszawa 2014.

Sobczak M., Wolność sumienia $i$ wyznania, jej gwarancje w systemie prawnym Rady Europy oraz w orzecznictwie Europejskiego Trybunatu Praw Człowieka w Strasburgu, Ius Novum 2008, nr 3.

Taczkowska-Olszewska J., Racjonalizacja wolności prasy - od modelu absolutnego do warunkowego. Europejski i krajowy kontekst wykładni prawa, Przegląd Sejmowy 2018, nr 1.

Wąsek A., Ochrona uczuć religijnych w prawie karnym, w: Prawo wyznaniowe III Rzeczypospolitej, red. H. Misztal, Lublin-Sandomierz 1999.

Wąsek A., Przestepstwa przeciwko przekonaniom religijnym de lege lata $i$ de lege ferenda, Państwo i Prawo 1995, z. 7. 
Wildhaber L., The right to offend, shock or disturb? Aspects of freedom of expression under the European Convention of Human Rights, The Irish Jurist 2001, t. 36.

Wiśniewski A., Koncepcja marginesu oceny w orzecznictwie Europejskiego Trybunału Praw Człowieka, Gdańsk 2008.

Wiśniewski A., O symbolach religijnych w orzecznictwie strasburskim, Gdańskie Studia Prawnicze 2013, t. 29.

Wiśniewski A., Proporcjonalność i fair balance w orzecznictwie Europejskiego Trybunatu Praw Człowieka, Gdańskie Studia Prawnicze 2019, nr 2.

Wiśniewski A., The European Court of Human Rights. Between Judicial Activism and Passivism, Gdańsk 2016.

Wółkowska M., Prawa kulturalne w Europejskiej Konwencji Praw Człowieka. Analiza w oparciu o orzecznictwo Europejskiego Trybunału Praw Człowieka w Strasburgu, Studia Iuridica Toruniensia 2013, t. 13.

\section{Streszczenie}

Sprawa Tagiyev i Huseynov v. Azerbejdżan jest punktem wyjścia, by po raz kolejny przyjrzeć się kolizyjności wolności wypowiedzi i wolności wyznania. Zagadnienie nie jest czysto teoretyczne, a jego skutki mogą być tragiczne i nie dotyczą wyłącznie Azerbejdżanu.

ETPC od kilkudziesięciu lat tworzy standardy orzekania w podobnych sprawach. Artykuł jest próbą ich zaprezentowania i zwrócenia uwagi na punkty kluczowe w procesie ważenia obu wolności oraz decydowania przez Trybunał, której z wolności dać pierwszeństwo. To prowadzi do decyzji, czy ingerencja państwa była uzasadniona i czy Konwencja została naruszona. Autorka stoi na stanowisku, że wraz z rozwojem nowoczesnych mediów o zasięgu globalnym i radykalizacji rozpowszechnianych w przestrzeni publicznej poglądów i przekonań przedstawicieli różnych grup społecznych do kolizji wolności wypowiedzi i wolności wyznania będzie dochodzić coraz częściej. ETPC proponuje w orzeczeniach konkretne wskazówki, jak w takich sprawach orzekać.

Słowa kluczowe: wolność wypowiedzi, wolność wyznania, Europejski Trybunał Praw Człowieka, kolizja wolności 


\section{FREEDOM OF EXPRESSION AND FREEDOM OF RELIGION IN A FATAL COLLISION. SELECTED COMMENTS BASED ON THE ECHR JUDGMENT OF 5 DECEMBER 2019 IN THE CASE OF TAGIYEV AND HUSEYNOV \\ V. AZERBAIJAN}

\section{Sum mary}

The case of Tagiyev and Huseynov v. Azerbaijan is the starting point for re-examining the collision of freedom of expression and freedom of religion. The issue is not purely theoretical, and it can have tragic effects applicable beyond Azerbaijan.

The ECHR has been setting the standards for adjudicating in similar cases for several decades. The article is an attempt to present those standards and draw attention to the key points in the process of assessing the two freedoms and deciding which one should be given priority. This in turn leads to the decision whether the state interference was justified and whether the Convention was violated. The author's position is that, along with the development of the modern global media and the radicalization of views and beliefs that are disseminated in the public sphere by members of various social groups, the collisions between freedom of expression and freedom of religion will occur more and more frequently. The ECHR sets out specific guidelines on how to adjudicate in such cases.

Key words: freedom of expression, freedom of religion, European Court of Human Rights, collision of freedoms

\section{СВОБОДА ВЫРАЖЕНИЯ МНЕНИЙ И СВОБОДА РЕЛИГИИ}

В «СТОЛКНОВЕНИИ СО СМЕРТЕЛЬНЫМ ИСХОДОМ». КОММЕНТАРИИ, ОТОБРАННЫЕ НА ОСНОВАНИИ ПОСТАНОВЛЕНИЯ ЕВРОПЕЙСКОГО СУДА ПО ПРАВАМ ЧЕЛОВЕКА (ЕСПЧ) ОТ 5 ДЕКАБРЯ 2019 Г. ПО ДЕЛУ ТАГИЕВ И ГУСЕЙНОВ ПРОТИВ АЗЕРБАЙДЖАНА

\section{Резюме}

Дело «Тагиев и Гусейнов против Азербайджана» является отправной точкой для того, чтобы вновь рассмотреть коллизию свободы выражения мнений и свободы религии. Этот вопрос не является чисто теоретическим, и его последствия могут быть трагическими и распространяются не только на Азербайджан.

ЕСПЧ устанавливает стандарты в такого рода делах на протяжении нескольких десятилетий. Эта статья является попыткой представить их и привлечь внимание к ключевым моментам в процессе «взвешивания» обеих 
свобод, а также в процессе принятия решений Судом, в отношении признания приоритетности одной из свобод. Это приводит к принятию решения о том, было ли вмешательство государства оправданным и была ли нарушена Конвенция. Позиция автора заключается в том, что по мере развития современных глобальных СМИ и радикализации взглядов и убеждений различных социальных групп, распространяемых в публичном пространстве, все чаще будут вступать в коллизию свобода выражения мнения и свобода религии. ЕСПЧ в постановлениях предлагает конкретные указания о том, как выносить решения по таким делам.

Ключевые слова: свобода выражения мнений, свобода религии, Европейский суд по правам человека, коллизия свобод 
